\title{
Correlation of incontinence impact questionnaire score in overactive bladder syndrome cases with urodynamic findings
}

\author{
Jai B. Sharma*, Mukul Chauhan, Neerja Bhatla, Amlesh Seth, \\ Rajesh Kumari, Bharti Uppal, Janmeeta Singh
}

Department of Obstetrics and Gynaecology, All India Institute of Medical Sciences, New Delhi, India

Received: 13 November 2020

Accepted: 09 December 2020

*Correspondence:

Dr. Jai B. Sharma,

E-mail: jbsharma2000@gmail.com

Copyright: (C) the author(s), publisher and licensee Medip Academy. This is an open-access article distributed under the terms of the Creative Commons Attribution Non-Commercial License, which permits unrestricted non-commercial use, distribution, and reproduction in any medium, provided the original work is properly cited.

\begin{abstract}
Background: Overactive bladder syndrome $(\mathrm{OAB})$ is a common condition. The aim of the present study was to correlate the incontinence impact questionnaire (IIQ) score with urodynamic studies in patients of overactive bladder syndrome.

Methods: It was a prospective study performed in a tertiary referral centre on 60 women with symptomatology of OAB. IIQ score was calculated and urodynamic studies were performed in all patients in which detrusor overactivity, maximum flow rate of urine per second (Qmax) and voiding time in seconds was calculated in all women.

Results: The mean age was $42.3 \pm 9.91$ years, mean body mass index was $24.7 \pm 2.71 \mathrm{~kg} / \mathrm{m}^{2}$, mean parity was 2.4 and mean serum creatinine level was $0.84 \pm 0.21 \mathrm{mg} / \mathrm{dl}$. Symptoms seen were urgency $(100 \%)$, frequency $(100 \%)$, urge incontinence $(95.0 \%)$ and nocturia (76.6\%). IIQ score ranged from 7-20 with mean being 12.27 \pm 3.38 . OAB was mild in $36.6 \%$, moderate in $41.66 \%$ and severe in $21.66 \%$ patients. On urodynamic studies, detrusor overactivity was present in $75 \%$ cases being $59 \%$ in mild, $80 \%$ in moderate and $76.92 \%$ in severe OAB. Mean $Q_{\max }$ increased with severity of $\mathrm{OAB}$ and was $29.55 \mathrm{ml} / \mathrm{second}$ in mild $\mathrm{OAB}, 30.36 \mathrm{ml} / \mathrm{second}$ in moderate $\mathrm{OAB}$ and $31.59 \mathrm{ml} / \mathrm{second}$ in severe OAB. Mean voiding time decreased with severity of OAB and was 33.44 seconds in mild OAB, 32.14 seconds in moderate $\mathrm{OAB}$ and 31.47 seconds in severe $\mathrm{OAB}$.
\end{abstract}

Conclusions: IIQ score and urodynamic studies are useful in diagnosis and quantification of OAB syndrome.

Keywords: Incontinence impact questionnaire score, Overactive bladder syndrome, $\mathrm{Q}_{\max }$, Urge incontinence, Urodynamic studies, Voiding time

\section{INTRODUCTION}

Overactive bladder syndrome (OAB) is a symptom complex characterised by urinary urgency, with or without urge incontinence, usually associated with increased day-time frequency and nocturia in absence of any infection or obvious pathology. ${ }^{1,2}$ Overall prevalence of $\mathrm{OAB}$ is about $12.8-14.3 \%$ in women. ${ }^{1,2}$ It has been shown to have a negative influence on daily activities and health related quality of life especially mental health, work productivity, social relationships and sleep. ${ }^{1,2} \mathrm{OAB}$ is usually associated with involuntary contractions of detrusor muscle which may cause urge incontinence depending upon the response of the sphincter. In fact detrusor overactivity has been reported in about $64 \%$ of all patients of $\mathrm{OAB}$ on cystometry. ${ }^{3}$

Major risk factors for $\mathrm{OAB}$ include vaginal delivery, old age, menopause, obesity and chronic constipation. ${ }^{4,5}$ Exact pathophysiology of $\mathrm{OAB}$ is not known. However myogenic factors, neurogenic factors and urotheliogenic factors may play a role in its etiopathogenesis. ${ }^{3,4}$ Diagnosis is usually made by a careful history taking for urinary symptoms of $\mathrm{OAB}$ (urgency, frequency, urge incontinence and nocturia)., ${ }^{3,4}$ Voiding diary is a very useful tool to diagnose OAB. A simple three day voiding diary containing the time and volume of each void is very useful in diagnosis. Urodynamic studies are very useful 
in diagnosis and quantification of $\mathrm{OAB}$, to find whether detrusor overactivity is present or not, to calculate total urine voided at each micturition $\left(\mathrm{V}_{\max }\right)$ and total voiding time. ${ }^{6-8}$ Urodynamic studies are also used for prognostication of various treatment outcomes including Mirabegron therapy. ${ }^{8}$ Yoo et al from South Korea studied prevalence of various lower urinary tract symptoms including $\mathrm{OAB}$ in population aged 40 years or over. ${ }^{9}$

We present our study on 60 women with overactive bladder syndrome diagnosed on symptoms and correlation of severity of OABS as per their incontinence impact questionnaire (IIQ) score and urodynamic study findings.

\section{METHODS}

It was a prospective study conducted in department of Obstetrics and Gynecology and Urology of a tertiary referral centre over 60 women with symptoms of overactive bladder syndrome between January 2017 and November 2018.

\section{Inclusion criteria}

Inclusion criteria were women above 18 years of age with clinical history and symptoms of OAB (urgency, frequency, nocturia with or without urge incontinence) with no significant medical problems and patients who were willing to participate in the study.

The study was granted ethical clearance by the Institute Ethical Committee. Informed consent was taken from all the participants.

A detailed clinical history was taken about symptoms of $\mathrm{OAB}$ including urgency, urinary frequency, nocturia and urge incontinence, past and present history of any medication including anticholinergics and medical disorder. Detailed general physical, systemic and pelvic examination was performed in all the cases. Baseline investigations (haemogram, blood sugar, renal and hepatic function tests, urine analysis) were performed in all the cases. Incontinence impact questionnaire (IIQ) score was taken as follows.

Table 1: Incontinence impact questionnaire.

\begin{tabular}{|lllll|}
\hline Question & Score & & Moderately & Greatly \\
\hline Do you experience, and if so, how much are you bothered by: & Not at all & Slightly & - & 3 \\
\hline Frequent urination? & 0 & 1 & 2 & 3 \\
\hline Urine leakage related to the feeling of urgency? & 0 & 1 & 2 & 3 \\
\hline Urine leakage related to physical activity, coughing or sneezing? & 0 & 1 & 2 & 3 \\
\hline Small amounts of urine leakage (drops)? & 0 & 1 & 2 & 3 \\
\hline Difficult emptying your bladder? & 0 & 1 & 2 & 3 \\
\hline Pain or discomfort in lower abdomen/ genital area? & 0 & 1 & 2 & Moderately \\
\hline Has urine leakage or prolapse affected your: & Not at all & Slightly & 2 \\
\hline Ability to do household chores? & 0 & 1 & 2 & 3 \\
\hline Physical recreation such as walking, swimming, or other exercise? & 0 & 1 & 2 & 3 \\
\hline Entertainment activities (movies, concerts, etc.)? & 0 & 1 & 2 & 3 \\
\hline Ability to travel by car or bus more than 30 minutes from home? & 0 & 1 & 2 & 3 \\
\hline Participation in social activities outside your home? & 0 & 1 & 2 \\
\hline Emotional health (nervousness, depression, etc.)? & 0 & 1 & 2 & 3 \\
\hline Feeling frustrated? & 0 & 1 & 2 \\
\hline
\end{tabular}

Sum of score $=$ OAB was classified into mild OAB (IIQ 7-10), moderate OAB (IIQ 11-15) and severe OAB (IIQ 16-20).

After taking informed consent, urodynamic evaluation was done in department of Urology seeing detrusor overactivity, $\mathrm{V}_{\max }$ (total urine voided at each micturition) and voiding time in seconds were calculated in all the cases.

The findings of urodynamic studies (detrusor overactivity, $\mathrm{Q}_{\max }$ and voiding time) were correlated with different severity of $\mathrm{OAB}$ as per IIQ score to see the effect of severity of $\mathrm{OAB}$ on urodynamic parameters.

\section{Statistical analysis}

Descriptive statistics such as mean, median, standard deviation and range values were calculated for study characteristics like age, body mass index and duration of symptoms. Continuous variables were tested for normality assumptions using Kolmogrov Smirnov tests, Chi square test or Fisher's exact test was used for frequencies of categorical variations. A two tailed probability level with $\mathrm{p}<0.05$ was considered for statistical significance. All data analysis were carried out using IBM SPSS statistics for windows version 19.0 New York IBM Corp. 


\section{RESULTS}

The baseline characteristics of 60 women found to have overactive bladder syndrome are depicted in Table 2 . The age ranged from 29-68 years with mean being $42.3 \pm 9.91$ years. Parity ranged from 0 to 5 with mean being 2.4 . Body mass index ranged from 20.02 to $32.7 \mathrm{~kg} / \mathrm{m}^{2}$ with mean being $24.7 \pm 2.71 \mathrm{~kg} / \mathrm{m}^{2}$. Serum creatinine levels ranged from $0.4-1.1 \mathrm{mg} / \mathrm{dl}$ with mean being $0.84 \pm 0.21$ $\mathrm{mg} / \mathrm{dl}$.

Table 2: Baseline characteristics and symptomatology of overactive bladder syndrome patients $(\mathrm{N}=60)$.

\begin{tabular}{|c|c|c|c|c|}
\hline \multicolumn{5}{|l|}{ Age (years) } \\
\hline \multicolumn{2}{|l|}{ Range } & \multicolumn{3}{|l|}{$29-68$} \\
\hline \multicolumn{2}{|l|}{ Mean } & \multicolumn{3}{|l|}{$42.3 \pm 9.91$} \\
\hline \multicolumn{5}{|l|}{ Parity } \\
\hline \multicolumn{2}{|l|}{ Range } & \multicolumn{3}{|l|}{$0-5$} \\
\hline \multicolumn{2}{|l|}{ Mean } & \multicolumn{3}{|l|}{2.4} \\
\hline \multicolumn{5}{|c|}{ Body mass index $\left(\mathrm{kg} / \mathrm{m}^{2}\right)$} \\
\hline \multicolumn{2}{|c|}{ Range } & \multicolumn{3}{|l|}{$20.02-32.7$} \\
\hline \multicolumn{2}{|l|}{ Mean } & \multicolumn{3}{|l|}{$24.7 \pm 2.71$} \\
\hline \multicolumn{5}{|c|}{ Serum creatinine levels (mg/dl) } \\
\hline \multicolumn{2}{|c|}{ Range } & \multicolumn{3}{|l|}{$0.4-1.1$} \\
\hline \multicolumn{2}{|l|}{ Mean } & \multicolumn{3}{|l|}{$0.84 \pm 0.21$} \\
\hline \multirow{2}{*}{ Symptom } & \multirow{2}{*}{ No. } & \multirow{2}{*}{ Percentage } & \multicolumn{2}{|c|}{ Duration (months) } \\
\hline & & & Range & Mean \pm SD \\
\hline Frequency & 60 & 100 & $2-20$ & $7.45 \pm 2.87$ \\
\hline Urgency & 60 & 100 & $2-20$ & $7.38 \pm 2.85$ \\
\hline Nocturia & 46 & 76.6 & $0.5-10$ & $3.87 \pm 2.58$ \\
\hline $\begin{array}{l}\text { Urge } \\
\text { incontinence }\end{array}$ & 67 & 95.0 & $1-18$ & $4.71 \pm 2.98$ \\
\hline
\end{tabular}

Symptomatology of patients in the study is also shown in Table 2. Thus out of total 60 patients, all $60(100 \%)$ women had urgency of micturition and frequency of micturition which are the two major symptoms of overactive bladder syndrome. Urge incontinence was seen in $57(95 \%)$ patients while nocturia (night time urinary frequency) was seen in $46(76.6 \%)$ of patients.
Table 3: Incontinence impact questionnaire score and severity of OABS $(\mathrm{N}=60)$.

\begin{tabular}{|llll|}
\hline Range of IIQ score & \multicolumn{7}{l}{$\mathbf{7}-\mathbf{2 0}$} \\
\hline Mean score \pm SD & $12.27 \pm 3.38$ & \\
\hline Severity of OAB as per IIQ score \\
\hline Severity of OAB & IIQ score & No. & Percentage \\
\hline Mild OAB & $7-10$ & 22 & 36.6 \\
\hline Moderate OAB & $11-15$ & 25 & 41.66 \\
\hline Severe OAB & $16-20$ & 13 & 21.66 \\
\hline
\end{tabular}

The findings of incontinence impact questionnaire (IIQ) and severity of OAB as per IIQ score are shown in Table 3. IIQ score ranged from 7-20 with mean being 12.27 \pm 3.38 . OAB was further classified as per IIQ score as mild $\mathrm{OAB}$ with score in 7-10 range in which 22 $(33.6 \%)$ women were there. A total of $25(41.66 \%)$ women had moderate OAB with IIQ score of 11-15 while $13(21.66 \%)$ women had severe OAB with IIQ score of $16-20$.

Table 4: Findings on urodynamic studies overactive bladder syndrome patients $(\mathrm{N}=60)$.

\begin{tabular}{|lll|}
\hline \multicolumn{2}{|l|}{ Urodynamic parameters } & \\
\hline Detrusor overactivity & No. & Percentage \\
\hline Present & 45 & 75 \\
\hline Absent & 15 & 25 \\
\hline Qmax (maximum flow rate in $\mathbf{~ m l}$ second) \\
\hline Range & $19.3-43.2$ & \\
\hline Mean \pm SD & $32.08 \pm 6.24$ & \\
\hline Voiding time (in seconds) & \\
\hline Range & $24.8-51.0$ \\
\hline Mean \pm SD & $32.41 \pm 5.87$ \\
\hline
\end{tabular}

Findings in urodynamic studies in patients of $\mathrm{OAB}$ are shown in Table 4. Detrusor overactivity was present in 45 (75\%) women while it was absent in $15(25 \%)$ women. $\mathrm{Q}_{\max }$ (maximum flow rate of urine in $\mathrm{ml} /$ second) ranged from 19.3-43.2 $\mathrm{ml} / \mathrm{second}$ with mean being $32.08 \pm 6.24$ $\mathrm{ml} /$ second. Total voiding time in seconds ranged from 24.8-51.0 seconds with mean being $32.41 \pm 5.87$ seconds.

Table 5: Correlation of severity of OABS as per incontinence impact questionnaire score with detrusor overactivity on urodynamic studies $(\mathrm{N}=60)$.

\begin{tabular}{|c|c|c|c|c|c|c|c|}
\hline \multirow[t]{2}{*}{ Severity of OAB } & \multirow[t]{2}{*}{ IIQ score } & \multirow{2}{*}{$\begin{array}{l}\text { No. of } \\
\text { patients }\end{array}$} & \multicolumn{2}{|c|}{$\begin{array}{l}\text { Presence of detrusor overactivity } \\
\text { on urodynamic studies }\end{array}$} & \multirow[t]{2}{*}{$P$ value } & & \multirow[t]{2}{*}{ Significance } \\
\hline & & & Number & Percentage & & & \\
\hline Mild OAB & $7-10$ & 22 & 13 & 59 & 1 versus 2 & 0.01 & Significant \\
\hline Moderate OAB & $11-15$ & 25 & 20 & 80 & 1 versus 3 & 0.02 & Significant \\
\hline Severe OAB & $16-20$ & 13 & 10 & 76.92 & 2 versus 3 & 0.58 & Not Significant \\
\hline
\end{tabular}

Table 5 depicts the presence of detrusor overactivity in different types of $\mathrm{OAB}$ as per incontinence impact questionnaire (IIQ) score. Detrusor overactivity was observed in $13(59 \%)$ patients of mild OAB but increased to $20(80 \%)$ in moderate $\mathrm{OAB}$ and was seen in 10 $(76.92 \%)$ patients of severe OAB. There was 
significantly higher incidence of detrusor overactivity in moderate and severe $\mathrm{OAB}$ as compared to mild $\mathrm{OAB}(\mathrm{p}$ value 0.01 in 1 versus 2 and 0.02 in 1 versus 3 ). However the difference in incidence between moderate and severe $(80 \%$ versus $76.92 \%)$ was not significant $(\mathrm{p}=0.58)$.

Table 6: Correlation of severity of $\mathrm{OAB}$ as per incontinence impact questionnaire score with $\mathrm{Q}_{\max }$ (maximum voided volume of urine/second) on urodynamic studies $(\mathrm{N}=60)$.

\begin{tabular}{|lllllll|}
\hline Severity of OAB & IIQ score & No. of patients & $\mathbf{Q}_{\max }(\mathbf{m l} / \mathbf{s e c})$ & P value & \multicolumn{2}{l|}{ Significance } \\
\hline Mild OAB & $7-10$ & 22 & 29.55 & 1 versus 2 & 0.08 & Not Significant \\
\hline Moderate OAB & $11-15$ & 25 & 30.36 & 2 versus 3 & 0.06 & Not Significant \\
\hline Severe OAB & $16-20$ & 13 & 31.59 & 1 versus 3 & 0.04 & Significant \\
\hline
\end{tabular}

Table 7: Correlation of severity of $\mathrm{OAB}$ as per incontinence impact questionnaire score with voiding time (in seconds) on urodynamic studies $(\mathrm{N}=60)$.

\begin{tabular}{|lllllll|}
\hline Severity of OAB & IIQ score & No. of patients & Mean voiding time (in seconds) & P value & Significance \\
\hline Mild OAB & $7-10$ & 22 & 33.44 & 1 versus 2 & 0.041 & Significant \\
\hline Moderate OAB & $11-15$ & 25 & 32.14 & 2 versus 3 & 0.038 & Significant \\
\hline Severe OAB & $16-20$ & 13 & 31.47 & 1 versus 3 & 0.027 & Significant \\
\hline
\end{tabular}

Correlation between severity of $\mathrm{OAB}$ as per IIQ score with mean maximum voided volume of urine in $\mathrm{ml} / \mathrm{second}\left(\mathrm{Q}_{\max }\right)$ is shown in Table 6. Thus mean $\mathrm{Q}_{\max }$ was $29.55 \mathrm{ml} /$ second in mild $\mathrm{OAB}$, which increased to $30.36 \mathrm{ml} / \mathrm{sec}$ nd in moderate OAB $(\mathrm{p}-0.08$ not significant) and to $31.59 \mathrm{ml} / \mathrm{second}$ in severe OAB (p0.06 not significant). However the difference between mild and severe OAB was significant (p-0.04).

Table 7 shows correlation of severity of OAB as per IIQ score with mean voiding time on urodynamic studies. Mean voiding time was 33.44 seconds in mild OAB. It decreased to 32.14 seconds in moderate OAB. The difference was statistically significant $(p=0.041)$. Mean voiding time further decreased to 31.47 seconds in severe $\mathrm{OAB}(\mathrm{p}=0.038)$ and the difference was significant. There was a significant fall in mean voiding time as the severity of OAB increased (mild versus severe 0.027).

Hence as per increase in severity of OAB on IIQ, time to void urine decreased significantly.

\section{DISCUSSION}

Overactive bladder syndrome is a common urogynaecological condition associated with significant economic and health related quality of life burden. Various studies have confirmed that women with $\mathrm{OAB}$ have significantly lower quality of life with increased anxiety, depression and less likely to be employed. ${ }^{1-4}$

Incontinence impact questionnaire (IIQ) is a clinical tool used to diagnose and quantify overactive bladder syndrome $(\mathrm{OAB})$ and takes into consideration experience and botheration by frequent urination, urgency, urinary leakage, physical activity, smell of urine, difficulty in emptying the bladder and any pain or discomfort in lower abdomen. $^{2}$ It also takes into consideration the effect of urinary leakage on ability to do household chores, physical activities, entertainment activities, travelling, participation in social activities, emotional issues (nervousness, depression) and feeling of frustration. Each point is quantified whether it is absent, sight, moderate or severe. ${ }^{2}$ In the present study IIQ was calculated for all 60 $\mathrm{OAB}$ patients and patients were divided into mild $\mathrm{OAB}$ (score 7-10), moderate OAB (score 11-15) and severe $\mathrm{OAB}$ (score 16-20) with highest incidence of moderate OAB $(41.66 \%)$. IIQ has a good correlation with severity of $\mathrm{OAB}$ as has been observed by various authors. ${ }^{9-13}$

In the present study, severity of OABS as per IIQ was correlated with urodynamic findings of detrusor overactivity, $\mathrm{Q}_{\max }$ (maximum flow rate of urine per second) and voiding time (in seconds). Urodynamic studies are very useful in diagnosis of OAB especially detrusor overactivity (DO) with prevalence of DO being $60-70 \%$ in OAB cases. In the present study prevalence of detrusor overactivity was overall $75 \%$ in OAB patients being $59 \%$ in mild $\mathrm{OAB}$ and $80 \%$ in moderate and $76.92 \%$ in severe OAB. Overall mean $\mathrm{Q}_{\max }$ (maximum flow of urine per second) was $32.08 \pm 6.24 \mathrm{ml} / \mathrm{second}$ in $\mathrm{OAB}$ patients being $29.55 \mathrm{ml} / \mathrm{second}$ in mild $\mathrm{OAB}$, rising to $30.36 \mathrm{ml} /$ second in moderate $\mathrm{OAB}$ and 31.59 $\mathrm{ml} /$ second in severe OAB. Similarly mean voiding time (in seconds) was $32.41 \pm 5.87$ seconds being 33.44 seconds in mild $\mathrm{OAB}, 32.14$ seconds in moderate $\mathrm{OAB}$ 31.47 seconds in severe $\mathrm{OAB}$ (significant decrease). Various studies by different authors have confirmed the utility of Qmax and voiding time in OAB. ${ }^{6-8}$

Overactive bladder syndrome score (OABS) has also been used to diagnose and quantify $\mathrm{OAB}$ and is a simple tool taking frequency of urine in day and night, urgency (sudden desire to pass urine and is difficult to defer) and urge incontinence into consideration. Various authors have used OABS for quantification of $\mathrm{OAB}$ and to see 
efficacy of drugs like solifenacin on OAB. ${ }^{14-16}$ Treatment of $\mathrm{OAB}$ includes bladder training, decrease fluid intake and pelvic floor muscle training. ${ }^{17,18}$ However, anticholinergic drugs like oxybutinin, tolterodine, solifenacin and darifenacin are mainstay in treatment of $\mathrm{OAB}$ and have proven efficacy in management of OAB but have significant side effects in the form of dry mouth, dry eyes and worsening of closed angle glaucoma. ${ }^{12,19,20}$ Their cumulative use can sometimes cause dementia, adverse functional and cognitive outcomes in older patients. ${ }^{21-23}$ Recently Mirabegron, a $\beta_{3}$ adrenergic drug has become available with high efficacy and better tolerance with least side effects but should be used with caution in cardiac patients and hypertensive patients. ${ }^{24,25}$

Some studies have proven that addition of both Mirabegron and Solifenacin increase the symptomatic relief more than monotherapy with either drug. ${ }^{26-28}$ Kuo et al recommend individualized treatment of overactive bladder syndrome patients. ${ }^{29}$ In the famous SYMPHONY trial, Abrams et al observed that Mirabegron in combination with Solifenacin or Darifenacin gave better results in treatment of $\mathrm{OAB}$ than either drug alone. ${ }^{30}$

\section{CONCLUSION}

Doppler sonography is an indispensable tool in overactive bladder syndrome is a common urogynaecological problem. It can be diagnosed by symptoms and quantified by incontinence impact questionnaire (IIQ) and urodynamic studies. There is a good correlation between severity of OAB on IIQ and urodynamic studies. However, larger multicentric prospective studies are recommended to prove these observations.

\section{ACKNOWLEDGMENTS}

The authors are thankful to all the faculty members and residents of department of Obstetrics and Gynaecology, Urology and Dr. Rishi Nayyar (Consultant Urology) for their help.

Funding: No funding sources

Conflict of interest: None declared

Ethical approval: The study was approved by the Institutional Ethics Committee

\section{REFERENCES}

1. Bo K, Frawley HC, Haylen BT, Abramov Y, Almeida FG, Berghmans B, et al. An International Urogynecological Association (IUGA)/International Continence Society (ICS) joint report on the terminology for the conservative and nonpharmacological management of female pelvic floor dysfunction. Int Urogynecol J. 2017;28(2):191213.

2. Cardozo L, Staskin D, Currie B, Wiklund I, Globe D, Signori M, et al. Validation of a bladder symptom screening tool in women with incontinence due to overactive bladder. Int Urogynecol J. 2014;25(12):1655-63.

3. Al-Zahrani AA, Gajewski J. Urodynamic findings in women with refractory overactive bladder symptoms. Int J Urol. 2016;23:75-9.

4. Zhu J, Hu X, Dong X, Li L. Associations between risk factors and overactive bladder: a meta-analysis. Female Pelvic Med Reconstr Surg. 2019;25:238-46.

5. Hagovska M, Švihra J, Buková A, Horbacz A, Dračková D, Švihrová V. Comparison of body composition and overactive bladder symptoms in overweight female university students. Eur J Obstet Gynecol Reprod Biol. 2019;237:18-22.

6. Hsiao SM, Wu PC, Chang TC, Chen $\mathrm{CH}$, Lin $\mathrm{HH}$. Urodynamic and bladder diary factors predict overactive bladder-wet in women: a comparison with overactive bladder-dry. Int Neurourol J. 2019 ;23:6974.

7. Jiménez-Cidre MA, López-Fando L, Mora AM. Clinical and urodynamic impact of detrusor overactivity in women with overactive bladder. Actas Urol Esp. 2019;43:221-7.

8. KoppKallner H, Elmér C, Altman D. Urodynamics as a prognosticator of mirabegron treatment outcomes. Gynecol Obstet Invest. 2019;21:1-5.

9. Yoo TK, Lee KS, Sumarsono B, Kim ST, Kim HJ, Lee HC, et al. The prevalence of lower urinary tract symptoms in population aged 40 years or over, in South Korea. Investig Clin Urol. 2018 ;59:166-76.

10. Abrams P, Cardozo L, Wagg A, Wein A, eds. Incontinence impact questionnaire. 6th edn. International Incontinence Society; 2017.

11. Monticone M, Frigau L, Mola F, Rocca B, Giordano A, Foti C, et al. Italian versions of the Urogenital Distress Inventory-6 and Incontinence Impact Questionnaire-7: translation and validation in women with urinary incontinence. Disabil Rehabil. 2020; $5: 1-7$.

12. Leron E, Weintraub AY, Mastrolia SA, Schwarzman P. Overactive bladder syndrome: evaluation and management. Curr Urol. 2018;11:117-25.

13. Wallace KM, Drake MJ. Overactive bladder. F1000Res. 2015;4.

14. Homma Y, Fujimura T. Psychometric validation of the English version of the overactive bladder symptom score. Urology. 2014;84:46-50.

15. Liu M, Wang J, Yang Y, An R, Wen J, Guan Z, et al. Overactive bladder symptom score to evaluate efficacy of solifenacin for the treatment of overactive bladder symptoms. Chin Med J. 2014;127:261-5.

16. Gotoh M, Kobayashi T, Sogabe K. Impact of symptom improvement on patients' bother and quality of life in female patients with overactive bladder treated by solifenacin (SET-Q). Int J Urol. 2014;21:505-11.

17. Kulaksizoğlu H, Akand M, Çakmakçi E, Gül M, Seçkin B. Effectiveness of pelvic floor muscle training on symptoms and uroflowmetry parameters 
in female patients with overactive bladder. Turk $\mathbf{J}$ Med Sci. 2015;45:449-53.

18. Fitz F, Sartori M, Girão MJ, Castro R. Pelvic floor muscle training for overactive bladder symptoms - A prospective study. Rev Assoc Med Bras. 2017;63:1032-8.

19. Willis-Gray MG, Dieter AA, Geller EJ. Evaluation and management of overactive bladder: strategies for optimizing care. Res Rep Urol. 2016;8:113-22.

20. Maman K, Aballea S, Nazir J, Desroziers K, Neine ME, Siddiqui E, et al. Comparative efficacy and safety of medical treatments for the management of overactive bladder: a systematic literature review and mixed treatment comparison. Eur Urol. 2014;65:75565.

21. Gray SL, Anderson ML, Dublin S, Hanlon JT, Hubbard R, Walker R, et al. Cumulative use of strong anticholinergics and incident dementia: a prospective cohort study. JAMA Intern Med. 2015;175:401-7.

22. Richardson K, Fox C, Maidment I, Steel N, Loke YK, Arthur A, et al. Anticholinergic drugs and risk of dementia: case-control study. BMJ. 2018;25(361):k1315.

23. Salahudeen MS, Chyou TY, Nishtala PS. Serum anticholinergic activity and cognitive and functional adverse outcomes in older people: a systematic review and meta-analysis of the literature. PLoS One. 2016;11:e0151084.

24. Shin DG, Kim HW, Yoon SJ, Song SH, Kim YH, Lee $\mathrm{YG}$, et al. Mirabegron as a treatment for overactive bladder symptoms in men (MIRACLE study): Efficacy and safety results from a multicenter, randomized, double-blind, placebocontrolled, parallel comparison phase IV study. Neurourol Urodyn. 2019;38:295-304.

25. Allison SJ, Gibson W. Mirabegron, alone and in combination, in the treatment of overactive bladder: real-world evidence and experience. Ther Adv Urol. 2018;10:411-9.
26. Drake MJ, Chapple C, Esen AA, Athanasiou S, Cambronero J, Mitcheson D, et al. Efficacy and safety of mirabegron add-on therapy to solifenacin in incontinent overactive bladder patients with an inadequate response to initial 4-week solifenacin monotherapy: a randomised double-blind multicentre phase 3B study (BESIDE). Eur Urol. 2016;70:13645.

27. Gibson W, MacDiarmid S, Huang M, Siddiqui E, Stölzel M, Choudhury N, et al. Treating overactive bladder in older patients with a combination of mirabegron and solifenacin: a prespecified analysis from the BESIDE study. Eur Urol Focus. 2017;3:629-38.

28. MacDiarmid S, Al-Shukri S, Barkin J, FianuJonasson A, Grise P, Herschorn S, et al. Mirabegron as add-on treatment to solifenacin in patients with incontinent overactive bladder and an inadequate response to solifenacinmonotherapy: responder analyses and patient-reported outcomes from the BESIDE study. J Urol. 2016;196:809-18.

29. Kuo HC. Individualizing medical treatment of overactive bladder. $\mathrm{Ci}$ Ji Yi Xue Za Zhi. 2018;30:195-9.

30. Abrams P, Kelleher C, Staskin D, Kay R, Martan A, Mincik I, et al. Combination treatment with mirabegron and solifenacin in patients with overactive bladder: exploratory responder analyses of efficacy and evaluation of patient-reported outcomes from a randomized, double-blind, factorial, dose-ranging, Phase II study (SYMPHONY). World J Urol. 2017;35:827-38.

Cite this article as: Sharma JB, Chauhan M, Bhatla N, Seth A, Kumari R, Uppal B, et al. Correlation of incontinence impact questionnaire score in overactive bladder syndrome cases with urodynamic findings. Int J Reprod Contracept Obstet Gynecol 2021;10:290-5. 